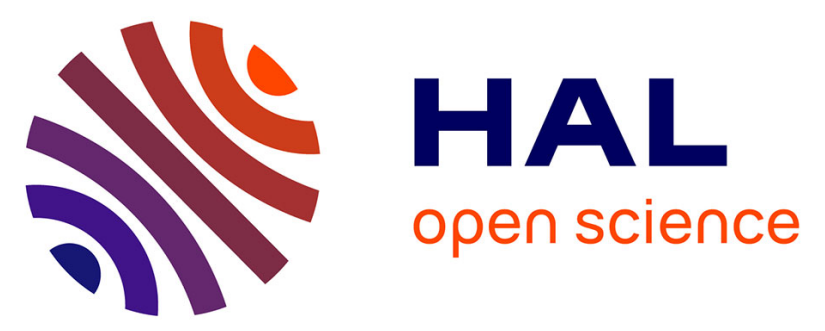

\title{
Prevention of iatrogenic infections in interventional rheumatology: Optimal measures but adapted to each risk
}

Yves Maugars, Jean-David Albert, Hervé Bard, Dominique Baron, Jean-Gérard Bloch, Pierre Bourgeois, Grégoire Cormier, Maria-Antonietta

D'agostino, Vincent Diebolt, Véronique Dixneuf, et al.

\section{To cite this version:}

Yves Maugars, Jean-David Albert, Hervé Bard, Dominique Baron, Jean-Gérard Bloch, et al.. Prevention of iatrogenic infections in interventional rheumatology: Optimal measures but adapted to each risk. Joint Bone Spine, 2016, 83 (3), pp.250-253. 10.1016/j.jbspin.2015.07.003 . hal-01217978

\section{HAL Id: hal-01217978}

\author{
https://hal-univ-rennes1.archives-ouvertes.fr/hal-01217978
}

Submitted on 16 Dec 2015

HAL is a multi-disciplinary open access archive for the deposit and dissemination of scientific research documents, whether they are published or not. The documents may come from teaching and research institutions in France or abroad, or from public or private research centers.
L'archive ouverte pluridisciplinaire HAL, est destinée au dépôt et à la diffusion de documents scientifiques de niveau recherche, publiés ou non, émanant des établissements d'enseignement et de recherche français ou étrangers, des laboratoires publics ou privés. 


\title{
Prevention of iatrogenic infections in interventional rheumatology: optimal
}

\author{
measures but adapted to each risk
}

Yves Maugars ${ }^{1}$, Jean-David Albert ${ }^{2}$, Hervé Bard ${ }^{3}$, Dominique Baron ${ }^{4}$, Jean-Gérard Bloch ${ }^{5}$, Pierre Bourgeois ${ }^{6}$, Grégoire Cormier ${ }^{7}$, Maria-Antonietta D'Agostino ${ }^{8}$, Vincent Diebolt ${ }^{9}$, Véronique Dixneuf $^{1}$, Fabien Etchepare ${ }^{6}$, Frédérique Gandjbakhch ${ }^{6}$, Philippe Gaudin ${ }^{10}$, Bertrand Lecoq ${ }^{11}$, Henri Lellouche $^{12}$, Pierre Monod ${ }^{13}$, Denis Rolland ${ }^{14}$, Jean-Philippe Sanchez ${ }^{15}$, Benoit Le Goff ${ }^{1}$, members of the SIRIS group ${ }^{16}$

\footnotetext{
${ }^{1}$ Rheumatology Department University Hospital, 1 place Alexis Ricordeau, 44093 Nantes cedex, France

${ }^{2}$ Rheumatology Department University Hospital 35000 Rennes, France

${ }^{3}$ Rheumatology 75007 Paris, France

${ }^{4}$ Lannion-Trestel Hospital 22660 Trévou-Tréguignec, France

${ }^{5}$ Rheumatology 67000 Strasbourg, France

${ }^{6}$ Rheumatology Department La Pitié-Salpétrière University Hospital 75013 Paris, France

${ }^{7}$ Rheumatology Department Hospital 85000 La Roche sur Yon, France

${ }^{8}$ Rheumatology Department Ambroise Paré Hospital 92104 Paris, France

${ }^{9}$ Rheumatology 67210 Obernai, France

${ }^{10}$ Rheumatology Department University Hospital 38000 Grenoble, France

${ }^{11}$ Rheumatology Department University Hospital 14000 Caen, France

${ }^{12}$ Rheumatology Department Lariboisière University Hospital 75010 Paris, France

${ }^{13}$ Rheumatology 11400 Castelnaudary,

${ }^{14}$ Rheumatology 18000 Bourges, France

${ }^{15}$ Rheumatology 64140 Billère, France

${ }^{16}$ Imaging and Interventional Rheumatology Group of the French Rheumatology Society, 75000 Paris, France
}

Correspondence: Yves Maugars, Rheumatology Department, Nantes University Hospital, 1 place Alexis Ricordeau, 44093 Nantes cedex, France;

fax 332400848 30: tel 332400848 25; mail yves.maugars@ chu-nantes.fr.

Keywords: interventional rheumatology, recommendation, asepsis, iatrogenic infection, prevention 
Osteoarticular iatrogenic infections may be serious and justify suitable and optimised preventive measures depending on each risk, as much in terms of mortality as of morbidity. Its appreciation has been the subject of more and more studies which allow the importance of the problem to be better evaluated. The level of iatrogenic infections after arthroscopy is evaluated at 1 to $5 \%$ on a recent series of knee operations, but they may be much higher for the elbow $[1,2]$. In practice, this examination is no longer used for diagnosis as it was 10 years ago, the progress in imagery means this invasive act is no longer necessary. In a recent meta-analysis, prosthetic surgery led to a level of deep iatrogenic infection of about $9 \%$ o for the hip, but with a confidence interval of 95\%, included between 4 and 22\%o [3]. Significantly, the existence of a perioperative wound with secondary infection is associated with iatrogenic infection. In $20 \%$ of the cases, these are Methicillin resistant staphylococcus. The level of infection for shoulder replacements is of the same magnitude of $10 \%$, but is around $20 \%$ o for knee replacements [4]. Prior cortisone local injections do not appear to increase the risk of later sepsis [5]. However, the increase in asepsis, with the implementation of laminar airflow in operating theatres, does not appear to increase the level of security for the considerable additional costs [6]. Although, it is clear that asepsis measures reduce the risk of iatrogenic infections, it is more difficult to determine the optimal threshold of preventive measures necessary without falling for an excess of costly and not very profitable measures.

Where are we with articular and periarticular local injections? At the present time, we only have retrospective inquiries available, with very low levels of iatrogenic infections, between 0.002 and $0.07 \%$ (table 1 )[7-13]. A prospective study will be very difficult to carry out with the necessary number of patients, in the hundreds of thousands with no losses, to follow-up, taking account of the rarity of the event. Two studies have recently been published after on 
the ground enquiries looking for the totality of real septic arthritis cases found in a given population $[7,11]$. However, the figures that have been discovered are particularly divergent: $0.026 \%$ (close to previous enquiries) for one and $0.37 \%$ for the other, i.e. a difference by a factor of 10. How do we explain this difference? If the number of sepsis has been the subject in the 2 exhaustive research studies, the methodology was quite different to evaluate the number of interventional local injections acts. In the Icelandic study, it is the number of acts charged for and reimbursed which was used. In the French study, a real evaluation over a 2 weeks period was carried out with $98 \%$ of rheumatologists in the region who perform $3 / 4$ of the local injections. In France, when a local injection is performed, the associated consultation may be quoted in the database and be reimbursed, without the act performed appearing. The database largely underestimates the number of acts performed. The French population is also much more important $(1,290,533$ versus 287,559$)$, with the number of acts retained more than 10 times greater $(75,698$ versus 6,891$)$. Furthermore, the local injection technique and asepsis used are unknown to the Icelandic Doctors, for a previous old period 1990-2002. In the French study, clean hands, with or without sterile gloves, single-use equipment and use of iodine or Chlorhexidine type antiseptics were the order of the day. The difference between the 2 figures is important: $0.37 \%$ and it is close to the 1 $5 \%$ of arthroscopies, which may justify operating type asepsis measures, whilst with only $0.026 \%$ this very low risk would not appear to justify additional preventive measures to what is actually practised and recommended in France by the HAS [14]. For our part, and in agreement with the results, the recommendations and practices carried out in France, we retain as level for iatrogenic infections after rheumatology interventions the figure of $0.026 \%$. 
The balance benefits - risks from local injections should be evaluated to estimate if the negative incidence of local injection risk is largely outweighed by the beneficial positive effects. The centres who practice and evaluate the benefits of osteoarticular local injections techniques find satisfaction levels reaching 90\% [15]. In the evaluation carried out by Zhou covering 771 interventional acts, the EVA fell from 6.7 to 2.4 after the therapeutic interventional act, with a NNT for an improvement of more than $50 \%$ to 1.4 [15]. latrogenic infection remains as the most serious complication, with risk of rapid articular destruction and definitive secondary functional impotence. If mortality from osteoarticular infections remains high, it is difficult to evaluate the importance of morbidity and mortality of these osteoarticular infections after local injections, based on the literature. Only one death has been found, related to an important diagnostic delay [16]. It remains that a patient informed of the risk should allow for rapid care and few sequelae. We can only insist on the indispensable character of patient information, better guarantee of early care for an eventual complication to avoid sequelae. The balance, benefit-risk however remains largely positive (Figure 1).

SIRIS (Section Imagerie et Rhumatologie Interventionnelle de la Société Française de Rhumatologie) (Imaging and Interventional Rheumatology Group of the French Rheumatology Society) proposes suitable preventive measures for each act depending on each particular patient risk and in each environment (Table 2). In fact, the septic risk depends on the type of act: the number of acts, the aggressive character and size of the cutaneous puncture, duration of the act. It is important to define the notion of sterile zone clean zone interface. So, the surgeons hand must be sterile, the same as all the parts of his body that contributes to movement near the operating site (sterile scrub). For acts with a simple cutaneous puncture, after asepsis of the skin with major antiseptics such as iodine or 
Chlorhexidine antiseptics, the choice may be made between the sterile - clean interface at the level of either the hand (sterile gloves and clean clothes), or either the needle or the syringe. On one hand, certain product syringes are not guaranteed sterile, and the problem of having a hand in a non-sterile glove which holds the syringe makes us consider that we should take account of the syringe-needle interface for simple acts. However, touching the needle or its connector should be avoided by introducing the "double no touch" notion, don't touch either the skin or the needle. Patients at risk also justify more additional measures: ageing, malnutrition, obesity, diabetic, prior surgery, haematopathy, cirrhosis, distant infections, carrying AIDS, iatrogenic (chemotherapy, biotherapy) and family immunodeficiency. Finally, the ambient surroundings need to be taken into account, with infection risk and germ virulence being different, depending on the place (medical office, radiology, clinic, hospital).

We have established these recommendations by taking into account the literature data, from an open enquiry with rheumatologists during a congress of the French Society of Rheumatology (after a communication in December 2011), and the advice from SIRIS experts (co-authors). We have seen that the techniques were very different from one person to another, with a clear increase in asepsis measures with the youngest. We propose recommendations albeit tempered, with a request for optimisation of each procedure, but without falling into the excess of precaution of the operation type, both costly and ineffective.

We have distinguished the usual acts, whether they are superficial or deep, periarticular (shoulder, elbow, wrist, hip, knee, ankle, foot, plantar fasciitis, trigger finger, finger retinaculum section), tunnels (carpel, tarsal, Morton, pelvis, shoulder), or articular (shoulder 
complex, elbow, wrist, finger, hip, knee, ankle, tarsal, foot, sternoclavicular, temporomandibular, zygapophyseal), more complex acts such as puncture aspiration of calcifications, cementoplasty, aponeurotomy, wrist retinaculum section, bone, synovial or muscular biopsies. Certain people are tempted to propose stricter prevention methods for deeper after local injections, such as the hip or sacroiliac. There is no data which allows this direction to be followed. Surveillance should simply be more precise concerning the absence of visible inflammatory signs for these deep articulations. Guidance (fluoroscopic, ultrasound or scan) may be an additional risk. It may be the environment of the $x$-ray table where all the potentially infected patients pass. Additional precautionary measures should be taken (level 2 ), and the room disinfected after each passage suspected of being an infection risk. Ideally, a room dedicated to osteoarticulations would be preferable. CT-scan requires several comings and goings between the guide and the image controls, which justifies additional precautions and also changing to level 2 . Ultrasound guidance presents a risk of contact with the probe, the needle should at all times be at least $1 \mathrm{~cm}$ away. Technical aids may be of use: an articulated arm to keep the probe close by without the need to rest it on another support, protecting the probe, the context of which will decide if this should be sterile or not, and a foot pedal to take the reference images. For all these guided acts, an assistant may be needed when the act is complex. However, for the more usual acts, there is no data justifying stricter precautionary measures for an ultrasound guided act compared to an act relying on anatomical guidance. The ASA score defines in anaesthesia the overall health state and the potential fragility of the patient. The HAS has established recommendations as to the optimal environment necessary to perform interventional acts [17]. This environment, with an eventual assistance for performing more complex acts, and above all surveillance after the interventional act will be adapted case by case for the ASA $3 \& 4$. The anaesthetic 
will remain local, with possible nerve or distal block. But an ASA 4 patients, locoregional proximal and plexus block anaesthetic techniques, and associated sedations justify the presence of a nearby anaesthetist. The characteristics of the required first aid kit are also specified. Note that the necessity to have an oxygen supply for level 1 (HAS recommendation) is far from unanimous for interventional rheumatologists. The quality of the environment or place where the act is performed is subject to a certain number of criteria between level 1 and 2, level 3 remaining as the operating theatre, but it is the cleanliness and its traceability that will be preponderant. A room or immediate surveillance area is required for level 2. Disinfection is required after the passage of an infected patient. Additional risk elements may envisage changing a patient from level 1 to level 2, on a case by case basis and depending on the practitioner's appreciation: infectious risk, general situation (ASA 3, poorly balanced), for example obvious allergic risk, anticoagulants or antiplatelets, morbid obesity, malnutrition, dementia. The HAS propose to define intermediate levels $2 a$ and $2 \mathrm{~b}$. The intermediate level $2 \mathrm{a}$ is a level 1 with reinforced asepsis (sterile gloves, sterile probe protection), with optional assistant, without however justifying the presence of an anaesthetist close by. This level 2 a could be used for risk patients (ASA 3 or infectious risk) and for the use of a mix of nitrous oxide $50 \%$ and oxygen $50 \%$ (gas and air). Level $2 \mathrm{~b}$ is the equivalent of level 2. It could be reinforced only if estimated to be necessary (antiseptic shower, sterile gloves and scrub, cap), in an environment close to those found in the operating theatre (level 3). Biopsy acts justify stricter asepsis measures as they include as secondary benefit a diagnosis dimension and not therapeutic.

In total, even if these recommendations should be indicators, that one can adapt case by case, nothing justifies an inflation of asepsis protection measures within the scope of 'principle of precaution' which may be just as useless as expensive if we consider the more 
than 2 million interventional rheumatology acts performed each year in France, with less than 100 septic complications of which less than 10 are subject to claims for damages.

There is no conflict of interest to be declared by the authors. 
1. Hagino T, Ochiai S, Watanabe $\mathrm{Y}$, Senga S, Wako M, Ando T, Sato E, Haro H. Complications after arthroscopic knee surgery. Arch Orthop Trauma Surg. 2014;134:1561-4.

2. Nelson GN, Wu T, Galatz LM, Yamaguchi K, Keener JD. Elbow arthroscopy: early complications and associated risk factors. J Shoulder Elbow Surg. 2014;23:273-8.

3. Lindeque B, Hartman Z, Noshchenko A, Cruse M. Infection after primary total hip arthroplasty. Orthopaedics. 2014;37:257-65.

4. Zimmerli W, Andrej Trampuz A, Ochsner PE. Prosthetic-Joint Infections. N Engl J Med 2004; 351:1645-1654.

5. McMahon SE, LeRoux JA, Smith TO, Hing CB Total joint arthroplasty following intra-articular steroid injection: a literature review. Acta Orthop Belg. 2013;79:672-9.

6. Gastmeier P, Breier AC, Brandt C. Influence of laminar airflow on prosthetic joint infections: a systematic review. J Hosp Infect. 2012 June;81(2):73-8.

7. Geirsson AJ, Statkevicius S, Víkingsson A. Septic arthritis in Iceland 1990-2002: increasing incidence due to iatrogenic infections. Ann Rheum Dis 2008;67:638-43.

8. Gray RG, Tenenbaum J, Gottlieb NL. Local corticosteroid injection treatment in rheumatic disorders. Semin Arthritis Rheum 1981;10:231-54.

9. Hollander JL. Intrasynovial corticosteroid therapy in arthritis. Md State Med J 1969;19:62-6.

10. Lebrun P, Sichere P, Hochard JC, Monod JL, Galin F. Evaluation of the practice of infiltration treatment: results of a questionnaire addressed to rheumatologists. Rev Rhum 1998;65:749 (Abstract 92).

11. Maugars $Y$, Glémarec J, Guillot $P$, Berthelot JM, Pot-Vaucel M, Le Goff $B$, working group in the SIRIS section. Infections iatrogènes après geste interventionnel ostéoarticulaire : incidence en Loire Atlantique en 2008. Revue du rhumatisme 2014;81:240-245.

12. Séror $P$, Pluvinage $P$, Lecoq d'Andrehttp://rheumatology.oxfordjournals.org/content/38/12/1272.full - aff-3\#aff-3 F, Benamou P, Attuil G. Frequency of sepsis after local corticosteroid injection (an inquiry on 1160000 injections in rheumatological private practice in France). Rheumatology 1999;38:1272-1274.

13. Weston VC, Jones AC, Bradbury N, Fawthrop F, Doherty M. Clinical features and outcome of septic arthritis in a single UK Health District 1982-1991. Ann Rheum Dis 1999;58:214-19.

14. Haute Autorité de Santé (French National Authority for Health) Hygiene and prevention of infectious risk in medical or paramedical surgery. ? Paris, June 2007. http://www.hassante.fr/portail/upload/docs/application/pdf/hygiene au cabinet medical recommandations $2007 \quad 1127 \quad 18 \quad 45 \quad 21 \quad 278 . p d f$

15. Zhou Y, Thompson S. Quality assurance for interventional pain management procedures in private practice. Pain Physician 2008;11:43-55.

16. Esenwein SA, Ambacher T, Kollig E, Kutscha-Lissberg F, Hopf F, Muhr G. Septic arthritis of the shoulder following intra-articular injection therapy. Lethal course due to delayed initiation of therapy. Unfallchirurg. 2002;105:932-8. 
17. Haute Autorité de Santé (French National Authority for Health) What level of technical environment to perform interventional acts in day care? Paris, December 2010.

http://www.has-sante.fr/portail/upload/docs/application/pdf/2011-

02/rapport definition environnements techniques.pdf 
Table 1: Level of iatrogenic osteoarticular infections in interventional rheumatology

for 1000 acts.

In France

Séror (Rheumatology 1999)

0.015

Lebrun (Rheumatologist Letter 1999)

0.015

Maugars (Rev Rhum 2013)

0.026

In Great Britain

Weston (Ann Rheum Dis 1999)

0.002

In the USA

Hollander (State Med J 1970)

0.067

Gray (Clin Orthop 1993)

0.020

In Iceland

Geirsson (ARD 2008)

$0.37 \%$ 
Table 2: SIRIS recommendations for patient, practitioner and material asepsis and adapted

environment for interventional rheumatology

\begin{tabular}{|c|c|c|}
\hline & $\begin{array}{c}\text { Level } 1 \\
\text { Usual injections and acts }\end{array}$ & $\begin{array}{c}\text { Level } 2 \\
\text { More complex injections and acts }\end{array}$ \\
\hline T PE OF INJECTION & $\begin{array}{l}\text {-periarticular (shoulder, elbow, wrist, hip, knee, ankle, } \\
\text { foot, plantar fascia, trigger finger, finger retinaculum } \\
\text { section }{ }^{a} \text { ) } \\
\text { - tunnels (carpal, tarsal, Morton, pelvic, shoulder) } \\
\text { - articular (shoulder complex, elbow, wrist, finger, hip, } \\
\text { sacroiliac, knee, ankle, tarsal, foot, sternoclavicular, } \\
\text { ATM, interapophyseal) } \\
\text { - epidural (interlaminar or caudal) or foraminal }\end{array}$ & $\begin{array}{l}\text { - Puncture aspiration of calcification, cementoplasty, } \\
\text { kyphoplasty, aponeurotomy, wrist retinaculum section } \\
\text { - bone, synovial or muscular biopsies }\end{array}$ \\
\hline PATIENT ASEPSIS & $\begin{array}{l}\text { local disinfection of the skin using iodine or } \\
\text { Chlorhexidine antiseptic, wait 2' (if alcohol solution: 30") } \\
\text { "no touch" skin procedure } \\
\text { clean in } 5 \text { steps if poor cleanliness }\end{array}$ & $\begin{array}{l}\text { local disinfection of the skin using iodine or } \\
\text { Chlorhexidine antiseptic, wait 2' (if alcohol solution: 30") } \\
\text { "no touch" skin procedure } \\
\text { clean in } 5 \text { steps if poor cleanliness }\end{array}$ \\
\hline $\begin{array}{l}\text { PRACTITIONER'S } \\
\text { ASEPSIS }\end{array}$ & $\begin{array}{l}\text { clean hands (hydroalcoholic gel) after each patient, non- } \\
\text { sterile gloves } \\
\text { paper mask, glasses if risk of projection } \\
\text { clean gown or clothes }\end{array}$ & $\begin{array}{l}\text { clean hands (hydroalcoholic gel) after each patient, } \\
\text { sterile gloves } \\
\text { paper mask, glasses if risk of projection } \\
\text { clean gown or scrub }\end{array}$ \\
\hline MATERIAL ASEPSIS & $\begin{array}{l}\text { single-use equipment } \\
\text { clean or sterile compresses and sterile syringe } \\
\text { "no-touch" sterile needle }\end{array}$ & $\begin{array}{l}\text { single-use equipment } \\
\text { clean or sterile compresses and sterile syringe } \\
\text { "no-touch" sterile needle }\end{array}$ \\
\hline GUIDED INJECTIONS & $\begin{array}{l}\text { Ultrasound: probe and cable cleaned with wipe or } \\
\text { antiseptic solution, non-sterile probe protection (+ non- } \\
\text { sterile gel), respect the distance needle - probe }>1 \mathrm{~cm} \\
\text { Fluoroscopy: protective material cleaned with antiseptic } \\
\text { after each patient }\end{array}$ & $\begin{array}{l}\text { Ultrasound: probe and cable cleaned with wipe or } \\
\text { antiseptic solution, sterile probe protection (+ non- } \\
\text { sterile gel), respect the distance needle - probe }>1 \mathrm{~cm} \\
\text { Fluoroscopy: protective material cleaned with antiseptic } \\
\text { after each patient }\end{array}$ \\
\hline PATIENT RISK & $\begin{array}{l}\text { High infectious risk judged important }{ }^{b} \text { : possible } \\
\text { evaluation case by case to pass to level } 2^{\text {a }} \\
\text { General acceptable risk: ASA }{ }^{c} 1-2 \text { even } 3 \\
\text { Anaesthesia: local or digital block or distal block }\end{array}$ & $\begin{array}{l}\text { High infectious risk: reinforced level } 2 \text { may be } \\
\text { considered }^{\text {d }} \\
\text { General risk: ASA }{ }^{c} 1-2-3 \text { even } 4 \\
\text { Anaesthesia: local or locoregional, plexus block, possible } \\
\text { associated sedation, gas and air } \\
\text { Anaesthetist available at proximity if necessary }\end{array}$ \\
\hline FIRST AID KIT & $\begin{array}{l}\text { Blood pressure instrument, stethoscope, oxygen }{ }^{\mathrm{e}} \text { (mask } \\
\text { or nasal canula) } \\
\text { SC adrenalin, SC atropine, corticoid, antihistamine } \\
\text { (+ analgesics, NSAIDs) } \\
\text { Optional: anticonvulsant, bronchodilator, intravenous } \\
\text { fluids }\end{array}$ & $\begin{array}{l}\text { Blood pressure instrument, stethoscope, thermometer, } \\
\text { ECG apparatus, oxygen (mask or nasal cannula), } \\
\text { oxymeter, intubation and aspiration cannula, } \\
\text { laryngoscope, ventilation mask, ventilator (manual or } \\
\text { automatic), defibrillator, } \\
\text { SC adrenaline, SC atropine, corticoid, antihistamine, } \\
\text { bronchodilator, ephedrine, anticonvulsant (Flumazenil } \\
\text { type), +/- muscle relaxant (Dantrolene type) }\end{array}$ \\
\hline
\end{tabular}




\begin{tabular}{|l|l|l|}
\hline & & $\begin{array}{l}\text { (+ analgesics, NSAIDs) } \\
\text { Intravenous perfusion material, physiological serum and } \\
\text { hyperosmolar solution }\end{array}$ \\
\hline ENVIRONMENT & $\begin{array}{l}\text { Fitted out consultation room: treatment area separate } \\
\text { from the office area, hygiene traceability, single-use } \\
\text { equipment, asepsis of potentially unclean elements } \\
\text { (reinforced for guided acts), circuit for waste disposal, } \\
\text { aeration, washable examination table, swivel lamp, } \\
\text { portable tablet, wash basin, closed cabinet } \\
\text { Optional assistant }\end{array}$ & $\begin{array}{l}\text { Fitted out consultation room with in addition: zone for } \\
\text { cleaning and disinfection, reinforced and regular } \\
\text { asepsis, decontamination zone, operating table (+/- } \\
\text { ventilation, sas (air-lock) entrance, electric generator) } \\
\text { Simple recovery room }\end{array}$ \\
Assistant
\end{tabular}

${ }^{a}$ possibility of an intermediate level 2a (sterile gloves, sterile probe protection, optional assistant)

${ }^{\mathrm{b}}$ ageing, malnutrition, obesity, diabetic, prior surgery, haematopathy, cirrhosis, distant infections, carrying AIDS, iatrogenic (chemotherapy, biotherapy) or family immunodeficiency

${ }^{\mathrm{c}}$ ASA score: $\mathbf{1}$ = patient normal $; \mathbf{2}$ = patient with moderated systemic anomaly; $\mathbf{3}$ = patient with severe systemic anomaly; $\mathbf{4}$ = patient with severe systemic anomaly representing a constant vital threat; $\mathbf{5}=$ patient moribund whose survival is unlikely without 'intervention

${ }^{\mathrm{d}}$ addition of cap and sterile scrub

${ }^{\mathrm{e}}$ this HAS recommendation for level 1 is not approved by the majority of the experts 
Figure 1: Balance benefits-risks from osteoarticular after local injections
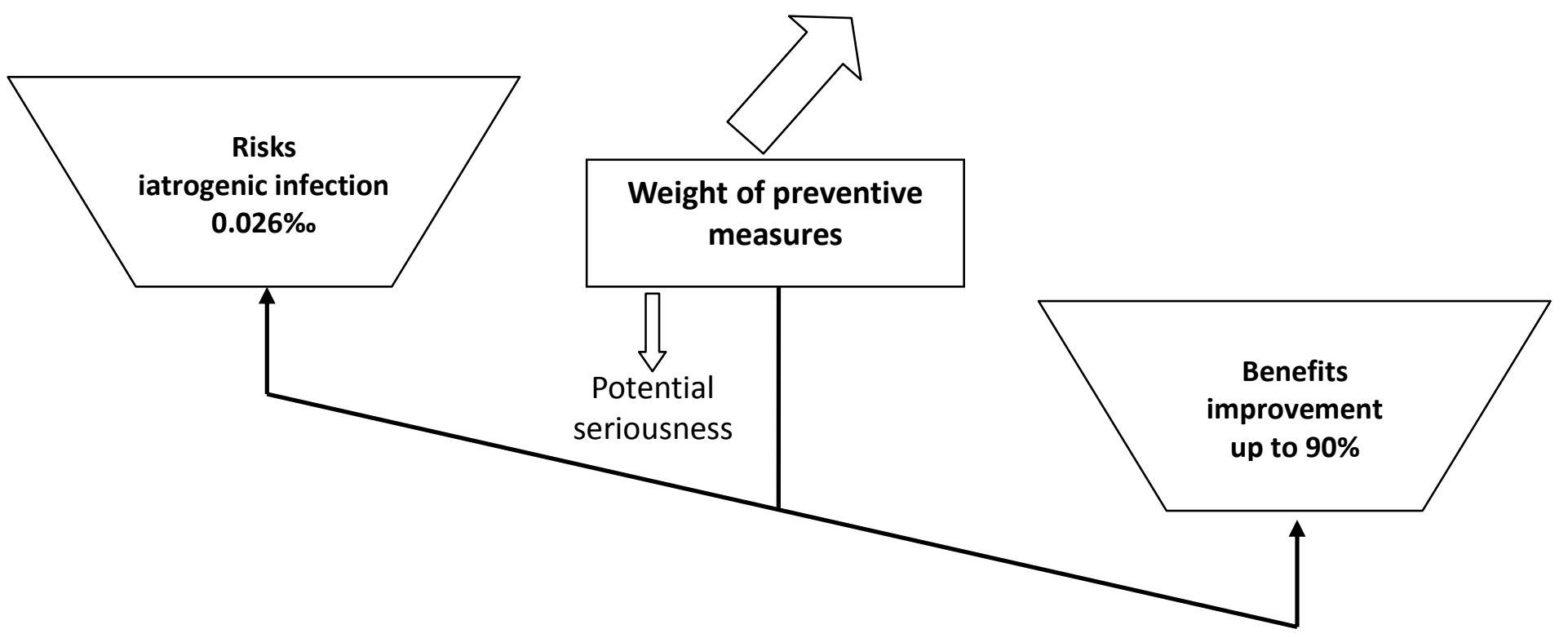